\title{
Revolutions Per Minute: A Symposium on the Sixties Counterculture in Aotearoa New Zealand
}

\author{
NICK BOLLINGER
}

Revolutions Per Minute: A Symposium on the Sixties Counterculture in Aotearoa New Zealand attracted a diverse group of academics, activists, historians, hippies and punters-withoutportfolio. 29 May 2021.

I had my own reasons for being there. I'm currently working on a book that sets out to tell the story of the counterculture in this country and, as this year's JD Stout Fellow, I have the privilege of completing my research and writing in the stimulating, collegial environment of the Stout.

The symposium gave me the chance to invite a mix of academics and practitioners, genders and generations, to talk and exchange ideas about their experiences and perceptions of the counterculture in this country.

What do I mean by the counterculture?

Though countercultures can be identified in all sorts of different periods of history, it was Theodore Roszak who brought the term into popular use in the late 1960s as a label for a particular group, born in the decade after the Second World War, who began to reach adulthood in the 1960s and would come to question, challenge and propose alternatives to the world as they found it. Roszak identified the emergence of what he called 'a culture so radically disaffiliated from the mainstream assumptions of our society that it scarcely looks to many as a culture at all but takes on the alarming appearance of a barbaric intrusion.'

Roszak, an American, had spent part of the Sixties in London editing a magazine called Peace News and his 1969 book The Making of a Counter Culture helped a group of disparate elements to see itself as an entity. The counterculture, as Roszak defined it, encompassed many different things: drug taking, mysticism, rock music, political protest, communitarian experiments, and more. His book was widely read, especially among those who thought they might be part of this barbaric intrusion, or liked the sound of it and wanted to know how they could join in. By the late Sixties, the term counterculture was in common use and remained so for much of the following decade.

The counterculture, when examined, can seem wildly diverse. As Roszak himself noted, a movement becomes harder to identify 'when one gets down to scrutinising the microscopic phenomena of history. At that level one tends only to see many different people doing many different things and thinking many different thoughts.'

Two particular issues helped unify this disparate group: nuclear weapons and the Vietnam War. A world that could devise such an effective means of destroying itself clearly had something wrong with it and demanded some sort of radical response, as did a superpower that would wage war against a people who were simply claiming the right of self-determination. 
Not that the counterculture necessarily responded in ways one would traditionally think of as political action. It often expressed itself in personal ways. To grow one's hair, experiment with drugs, explore forms of mysticism, live together without marrying or leave the city to start a commune all became, in their ways, political acts.

My inquiry centers on a few particular questions. How were countercultural ideas introduced in this country, how did they change once they got here and what, if anything, gave them their distinctive New Zealand character? And I am interested in how such ideas turned out in practice; which ones thrived, which ones faltered, and what might future generations learn from all of it?

The symposium was structured as five panel discussions. The first addressed the question of how countercultural ideas travelled in a pre-internet world and was introduced by Megan Simpson, whose MA thesis completed at Victoria University in 2007 looked at the Resistance bookshops of the late 60s and early 70s as a nexus for countercultural ideas and action. As she put it, 'Resistance played a part in helping to break up cultural taboos in New Zealand by making texts available that challenged conventional ways of life, was able to help spread ideas and foster change.'

Megan, a generation younger than the boomers of the counterculture, explained that her curiosity had initially been piqued by her father's copies of the Whole Earth Catalogue, a countercultural compendium published in the 70s in a New Zealand edition by Alister Taylor.

In the panel discussion that followed we heard from Jonathan Milne, a contemporary of Taylor's, who from 1969-1973 published the 'underground' magazine Earwig, and Roger Steele who edited the Victoria University Student's Association newspaper Salient in 1973 and 1974. Both magazines became vehicles for countercultural thought and organisation. In one of several instances of informants appearing unexpectedly from the crowd, the panel was joined by Richard Suggate, who had managed the Wellington Resistance Bookshop in the early 1970s.

Suggate, like Steele, spoke of his belief during this period that 'there was a revolution around the corner', and the significance of the war in Vietnam as a focus around which to unite a disparate group. He noted that after the end of the Vietnam war 'it became hard to maintain the illusion that there was some kind of united front'.

The second panel looked at the rise of intentional communities as a practical expression of countercultural ideas. Dr Olive Jones, whose 2011 doctoral thesis for the University of Waikato compared four communities, all of which had existed for at least twenty-five years, spoke of her own experience in helping establish the Graham Downs commune in Motueka, and the essentially anarchist principles on which it was founded. 'There was this really strong feeling that everything was about to implode and collapse and the world was just going to the dogs... and the only way to survive was to become self-sufficient.'

She described how, after thriving in its initial decade, the community itself imploded due to personality clashes, power struggles, opportunists and people with drug and mental health issues. 
Stephanie McKee, a founder of the Karuna Falls community in Coromandel which continues to this day, talked of encountering some of the same problems but dealing with them through the application of rules and protocols. 'We loved rules! We had a lot of protocols - meeting protocols, visitor protocols, and our internal building protocols. I guess we were quite middleclass in that way, but I think it helped us keep the community together.'

John Newton, whose book The Double Rainbow details the story of James K. Baxter's Jerusalem commune, discussed how Baxter's short-lived experiment was never intended to be selfsufficient but rather 'a lifeboat or ark... where the casualties of mainstream culture could find some sort of sanctuary'. Describing Baxter's community as 'a kind of performance art', he noted that at the time it 'projected a version of the Māori world into the media and into the Pākehā consciousness and even the consciousness of the Pākehā counterculture'.

The next panel looked at how the counterculture influenced and exerted its ideas on the protest movement. It was introduced by Roger Fowler whose history of protest began in the late 1960s as a conscientious objector to the Vietnam War. His activities included participating in the 'liberation' of Auckland's Albert Park at a time when political speeches and live music were forbidden there, and the formation of the Ponsonby People's Union, to provide legal and tenancy advice, cheap food, and support for Pasifika facing immigration battles. He also noted the way countercultural slogans such as 'Do It' and 'Power to the People' were subsequently appropriated by the mainstream and used in advertising campaigns by capitalist corporations.

Therese O'Connell spoke of arriving in Wellington in 1970, age eighteen, and joining the Progressive Youth Movement whose methods of protest encompassed street theatre, music and subversive publications. These included infiltrating the student capping 'prosesh' carrying cardboard coffins bearing the names of students recently killed by National guardsmen at Kent State University and handing out copies of The PYM Colouring Book at school gates. ('Here is a policeman pulling a demonstrator's hair. Policemen do nasty things when they are told to. The army men are worse. They will even kill people if the government tells them to ...')

She also noted the use of drugs in the counterculture and what she saw as their adverse effect on the protest movement. 'I didn't want an altered consciousness. Consciousness was scary enough anyway without it being altered! I sometimes thought the introduction of drugs was deliberately done to try and damp down the ardour of the revolutionary people, but that's my conspiracy theory.'

Outraged that the men she worked alongside at the university cafeteria were being paid more 'because they were men' she helped establish the Women's Liberation Front at Victoria University, borrowing the name from the Vietnamese Liberation Front.

The counterculture challenged traditional attitudes towards sex, marriage, domestic life, but who gained what? To address this question, Sue Kedgley read an excerpt from her recently published memoir Fifty Years a Feminist and Catherine Delahunty read from a work in progress.

Reflecting on her time as a student in the 1960s, Kedgley noted that the so-called sexual revolution had 'fuelled men's entitlement to sex and expectation that women would bet sexually

Journal of New Zealand Studies NS32 (2021), 183-186 https://doi.org/10.26686/jnzs.iNS32.6870 
available'. She quoted an 'odd' 1963 editorial in Salient, written by future Prime Minister Geoffrey Palmer, that warned of the damage to women's marriage prospects if they exercised their sexual freedoms.

Delahunty said that the counterculture legitimised the exploitation of women through such things as the lyrics of rock songs. 'I liked Jimi Hendrix but unfortunately he just had to shoot his woman down. Neil Young in 'Down by the River' - he had to shoot his woman as well! What's wrong with these guys?' Sexual freedom, she said, turned out only to be about freedom for men. Her experience in a commune in the 70s led her to believe it was even worse in the rural areas where 'men all had chainsaws and women were washing by hand in the creek. We were emulating some kind of hideous colonialism as though that was liberation.'

But Olive Jones, speaking 'in defence of sexual openness', noted that 'there was something intensely liberating about it as well' and had realised as a young woman 'that your sexuality was another tool of power'.

Comments from the floor introduced the question of class, and how much countercultural attitudes reflected a white middle-class privilege. Delahunty agreed that class was fundamental to the discussion, and that its absence from much of the counterculture's thinking - 'there was this idea that in the counterculture we were all magically on the bus together' - had been one of the movement's shortcomings.

In response to dissenting views in the room, she said: 'If you don't accept that class and patriarchy are real systems then it's quite hard to have this conversation about how we're going to change it because it all comes down to completely valid individual experiences. But if you don't look at things in system terms it's quite difficult to make change.'

In the final panel, Toby Boraman looked at what of the counterculture survived today, and weighed up some of its successes and failures. He pointed to the liberalisation of culture and increased acceptance of ideas such as organics, eco-villages, alternative religions, or simply 'being weird'.

At the same time, he noted that in freeing up the culture, the neoliberal governments of the 80s and 90s had also freed up the economy, using countercultural language as a smokescreen for economic reforms that led to greater inequalities.

Highlighting the countercultures's contradictions, he observed that it was individualistic and self-indulgent, with an emphasis on 'doing your own thing', while at the same time collectivist in its pursuit of communal living, co-operative organisations and mass gatherings. It was pessimistic in the way it foresaw military and ecological destruction, yet optimistic in its proposal of utopian alternatives. It was elitist and exclusive, white male and middle-class dominated, and yet it promoted ideas of tolerance, diversity and acceptance, some of which are now reaching the mainstream.

While the arguments continued after the last session had officially ended, and may still be going on somewhere for all I know, I returned to the Stout to examine the wealth of stories and ideas the symposium had produced, and to get on with writing the book. 